\title{
Tourism and Economic Development in Nigeria: A Critical Assessment of the Obudu Mountain Resort, Cross River State 2008-2018
}

\author{
Alexander Ugwukah* Victoria Sotonye Oluwayomi Obomanu \\ School of Education and Humanities, Babcock University, PO box 21244, Ilishan-Remo, Ogun State, Nigeria
}

\begin{abstract}
The Obudu Mountain Resort has been in existence for a long time and has gained prominence as a tourism destination both domestically and internationally. Despite its lofty attainments, it cannot be said that the resort has met the standards required for its status. Thus, the problem which this study has been confronted with is making a rigorous attempt to interrogate the debilitating factors which has restrained this resort from advancing to its expected goals and result-oriented profit margin. Primary Data for the study were collected through archival materials, interviews, and participatory observations. Secondary sources utilized include newspapers, internet sources and journals. Given the comparative research methodology which sought to ascertain the achievements of this tourism destination in Nigeria, the study discovered that the resort was highly deprived of adequate financial support since economic development deserves adequate financial investment. The research posited that what is currently invested cannot produce the expected revenue to ginger the very vital economic development of Cross River State of Nigeria.
\end{abstract}

Keywords: key words, Development, Diversification, Economic Growth, Tourism

DOI: $10.7176 / \mathrm{JTHS} / 48-03$

Publication date:March $31^{\text {st }} 2020$

\section{Introduction}

Nigeria is endowed with diverse mineral resources, cultural and natural heritage, making her one of Africa's largest economies. Given these fortunes, the economy has been plagued with the "Dutch epidemic", which has been exacerbated by the weak reliance on crude oil since its discovery in 1956 (Bankole, 2002). According to the Organization of Petroleum Exporting Countries (OPEC), the petroleum sector has gradually become the centrepiece of Nigeria's economy because it accounts for $10 \%$ of the gross domestic profit, $70 \%$ of the federal and state government revenue and up to $83 \%$ of the country's export, making other sectors almost dormant. Expediently, this dormancy can be expunged through the resuscitation of the tourism sector because the country possesses natural resources and cultural heritages that are the bases for tourism development (The economic context of Nigeria - Economic and Political Overview - Nordea Trade Portal, 2020)

According to Omolewa, tourism is essential to the life of nations because of its direct effect on the social, cultural, educational and economic sectors of national societies and on their international relations. It involves activities that are related to the display of the natural environment, historic and cultural heritage (Tourism capable of outshining oil as Nigeria's revenue earner-Omolewa, ex-UNESCO ambassador, 2020).The thirty-six states of Nigeria are endowed with diverse tourism potentials which include the forest reserves, game reserves, historical sites and the scenic resources (Cross River State Tourism (2019): Best of Cross River State - Tripadvisor, 2019).The Obudu Mountain Resort is an example of the scenic resources presented here as a case study. It is located in the southern part of Nigeria. The resort was formerly located in the Obudu local government, but as a result of overpopulation, more local governments were established. Therefore, the resort is reportedly situated within the Obanliku Local Government Area of the Cross River State as seen in Figure 1. 


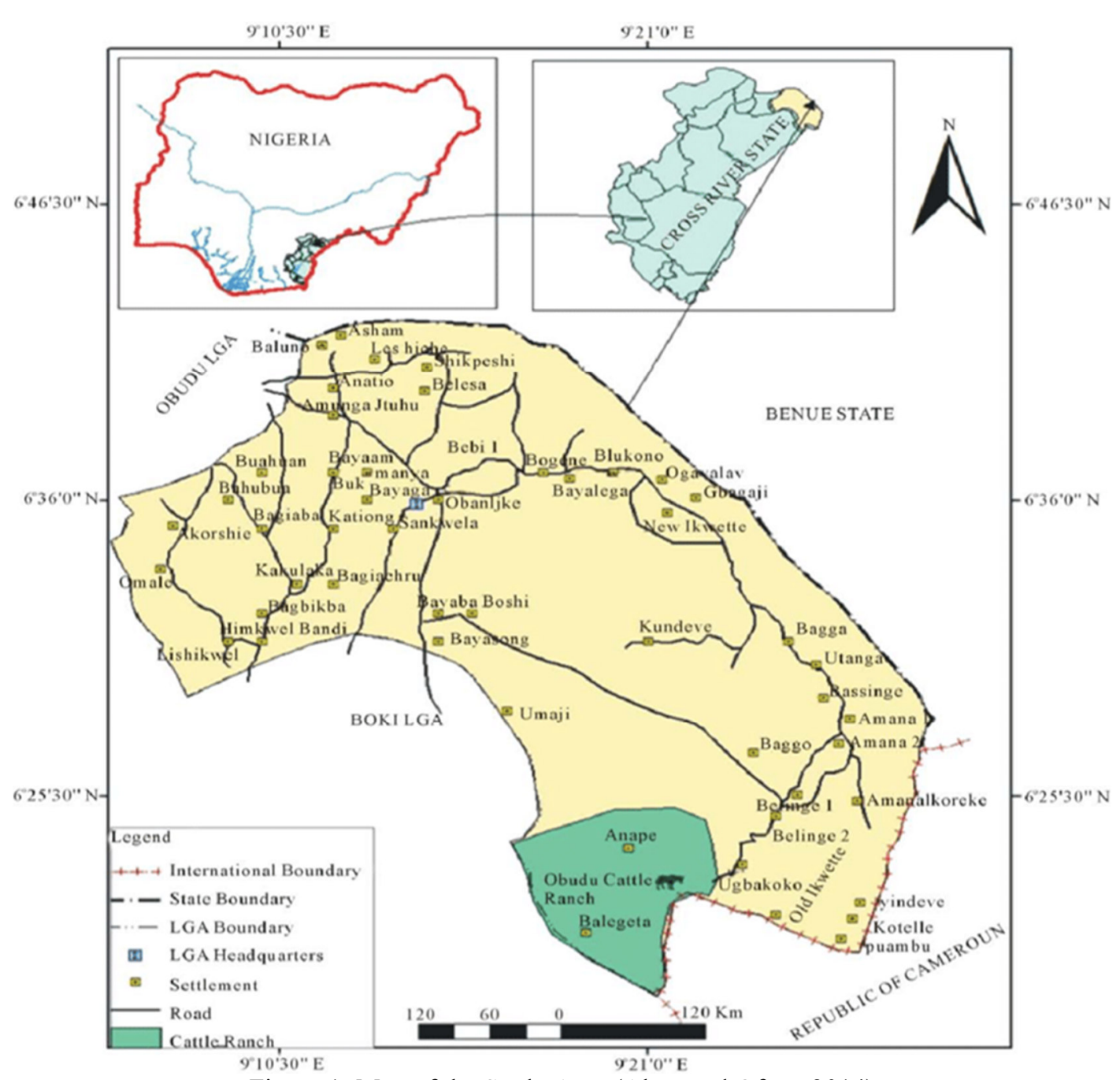

Figure 1: Map of the Study Area (Akpa and Ofem, 2014)

\subsection{Statement of the Problem}

Nigeria has been deficient in the growth of the tourism sector that other nations have been able to leverage for economic development. Tourism is the fastest growing sector in the world and has abundance of resources that is concerned with the display of the natural environment (natural attractions) and cultural heritage which Nigeria possesses. The deficiency in the growth of the tourism sector in Nigeria is because of these reasons; the overdependence on revenue from crude oil, inability of the government to formulate policies that promote tourism, lack of effective maintenance of tourism attractions, lack of implementation of the tourism master plan, poor infrastructural development, insecurity and the mismanagement of tourism assets. This is because the government has continued to pay lip service to the development of the sector which can generate wealth. The study therefore seeks not only to interrogate the contribution of tourism through the Obudu Mountain Resort to state and national economic growth but to critically assess the challenges of tourism in Nigeria and the challenges that are peculiar to the Obudu Mountain Resort. The study will also interrogate issues that have deprived the Obudu Mountain Resort from attaining such lofty heights as prescribed by the United Nations World Tourism Organization.

\subsection{Objective of the Study}

The main objective is to scrutinize the relevance of tourism as a framework for national development. The specific objectives of this research are to:

i. $\quad$ examine tourism and economic development in Nigeria

ii. interrogate the extent to which tourism serve as a tool for economic development in Nigeria

iii. ascertain the extent to which the Obudu Mountain Resort can engender economic development in Cross River State and Nigeria and

iv. examine the impact of tourism to national development 


\subsection{Research Questions}

The following research questions were formulated to guide the study:

i. What is the state of tourism in Nigeria?

ii. What is the relevance of tourism to economic growth?

iii. To what extent can the Obudu Mountain Resort engender economic development in Cross River State and Nigeria?

iv. What is the impact of tourism to national development?

\subsection{Significance of the Study}

The value of the tourism sector cannot be overemphasized because of its advantages and position as a commercial activity intertwined with other industries. Tourism plays a significant role in economic growth thus the ambitious idea behind this study. This study analysed tourism opportunities and proposed solutions to potential challenges to tourism development in Nigeria.

Therefore, the study aims to interrogate the growth of the tourism industry in Nigeria with Obudu Mountain Resort as the study's main thrust. It will also highlight the contribution of tourism to national economic growth and policies to enhance environmental sustainability, economic stability and diversification. The study would also promote economic diversification that has been a problem for decades.

\subsection{Scope of the Study}

The study focused on tourism development in Nigeria which is considered as a sector that propels economic growth, enhances economic diversification and sustainable development. The Obudu Mountain Resort is the main thrust of the study as its performance and impact to the attainment of sustainable tourism would be examined. The reason for the study is to use the Obudu Mountain Resort as a yardstick for other tourism attractions and to improve tourism in Nigeria, which can lead to rapid economic development.

\subsection{Operational Definition of Terms}

Economic Development: It is a term that describes the process by which the quality of life of a region or nation is improved based on targeted goals. (Economic Development, 2020)

Tourism: It is the act of travelling in pursuit of pleasure and recreation. (tourism : Definition, History, Types, Importance, \& Facts, 2020)

\subsection{Methodology}

This study adopted the historical research methodology, involving the qualitative and analytical approach in data collection. Sources of data were essentially primary sources that included oral information (interviews) from academics and prominent individuals in order to add substance to the study. While the secondary sources included journals, newspapers, text books and online materials that were relevant to the study. The interview guide was administered to respondents for the assessment of the Obudu Mountain Resort and its economic contribution to Cross River State and Nigeria. The essence is to draw inferences, conclusion and recommendation for deficiencies in the development of the tourism industry in Nigeria. Below are the lists of interview questions.

\subsection{Interview Questions}

1. What is the Origin or history of the Obudu Mountain Resort?

2. What are the facilities in the resort?

3. What are the factors affecting the growth of the tourism industry in Nigeria?

4. To what extent has the government aided the tourism sector in Cross River State?

5. What are the contributions of tourism to Nigeria's economy?

\section{LITERATURE REVIEW}

\subsection{Overview of Tourism Development in Nigeria}

The growth of tourism in Nigeria stems from the endowment of tourism resources such as vegetation, mountains, wildlife, waterfalls, valleys, and beaches located in different parts of the country. (Munzali, 2019). These natural endowments have made the country home to some of the United Nations World Heritage Sites. These World Heritage identified by United Nations Educational, Scientific and Cultural Organization (UNESCO) include, the Osun-Oshogbo Sacred Grove in Osun State identified in 2005, and the Sukur Cultural Landscape in Adamawa State identified in 1999. (The Top 10 Heritage Sites in Nigeria 2019).

Tourism development in Nigeria is traced to 1472 with the first Portuguese commercial mission-trade. The first attempt to manage tourism resources in Nigeria was in 1953 when the British established the Colonial Antiquities Commission (CAC) to identify and preserve monuments and antiques in Nigeria. The federal government formed an ad hoc committee to examine the feasibility of promoting the country's tourism after 
independence in 1960. The first attempt to structure tourism in Nigeria came in 1962 when a group of Nigerians with an interest in and commitment to tourism promotion set up an organization known as the Nigerian Tourism Association (NTA). Grants were received from the Nigerian government and the NTA became a member of the International Union of Official Travel Organization (IUOTO), now the United Nations World Tourism Organization (UNWTO) in 1964. The need for a more focused and direct government involvement in the tourism sector was evident in 1964, when the Nigerian Tourism Company (NTC) was registered as an institution of the government. From the 1960s to the 1970s, both the NTA and the NTC were in an uncomfortable coexistence. This was because of the lack of proper government and private investors' collaboration in tourism development.

In 1971, Nigeria's Federal Government gave the African Development Bank (ADB) the duty to perform a feasibility study on the development of tourism. The positive outcome of the study transformed the Nigeria Tourist Association (NTA) into the Nigeria Tourist Board (NTB), which was established by Decree No 54 of 1976 to fulfil the functions of the NTA. These functions are to provide facilities to ensure a good tourism experience and to encourage Nigerians to spend their holidays at home and attract foreign tourists. There has therefore been a change from the private sector to the government in performing these functions. The Nigeria Tourist Board was empowered to set up the National Travel Bureau (NTB) to coordinate packed tours in the country. The 1976 decree allowed the States of Nigeria to set up tourism committees to assist the tourism board. (Bankole, 2002). This illustrated the need to conceptualize the development of tourism within the national development plan.

In addition, tourism became a preferred sector in the Nigeria economy, leading to the establishment of the tourism policy and master plan. The tourism plan included guidelines on how to organize, develop and promote tourism products. It also emphasized the change that would result from the development proposals, as well as the social and economic effects of the plan proposed. In 1990, the Strategic Tourism Program initiated the National Tourism Policy Document, the Nigeria Tourism Board and the Ministry of Trade and Tourism created the tourism policy document. This was the first attempt by the Nigerian government to spell out the country's tourism goals. The consultation with foreign experts also provided a sense of direction in helping to map a development plan for tourism.

However, the National Tourism policy was successful but lacked practical steps to achieve their objectives. The key outcome of the strategy was to increase bureaucratization in the organization of government institutions without any change in management efficiency. This prompted the establishment of the Nigerian Tourism Development Corporation (NTDC) in 1992 under Decree 81 to boost the Nigeria Tourism Board's activities and oversee the development of tourism. The Ministry of Trade and Tourism controlled the NTDC, later called the Federal Ministry of Culture and Tourism (FMCT). The Ministry was later merged with the Ministry of Information to create the Federal Ministry of Information and Culture in 2015. (Adebayo, 2018).

\subsection{Tourism Potentials in Nigeria}

The rich cultural heritage of Nigeria has immense potential as it is a true tool for socio-economic development. This directly impacts the economy by providing resources and income that can be deployed to improve economic growth and promote development. Nigeria has an array of tourism attractions throughout the country as well as cultural festivals that reflect the heterogeneous nature of the country. Table 1 shows some of the tourism attractions in Nigeria and their locations. (Tourist Attractions in Nigeria, 2019).

Table 1: Tourism destinations and their locations (https://ww.cometonigeria.com)

\begin{tabular}{|l|l|l|}
\hline S/N & LOCATIONS & TOURISM DESTINATIONS IN NIGERIA \\
\hline 1 & Abia State & Arochukwu Cave and Azumini Blue River \\
\hline 2 & Adamawa State & Sukur Cultural Landscape and Lamurde Hot Spring \\
\hline 3 & Akwa Ibom State & Lord Lugard Residence and the Amalgamation House \\
\hline 4 & Anambra State & Idemili Cultural Centre and Ikenga Virgin Forest \\
\hline 5 & Bauchi State & Yankari Game Reserve and Wikki Warm Spring \\
\hline 6 & Bayelsa State & Nigeria's First Oil Well and Apoi Creek Forest \\
\hline 7 & Benue State & Ushongo Hills and Dajo Pottery \\
\hline 8 & Borno State & Sambisa Game Reserve and Lake Chad \\
\hline 9 & Cross River State & Obudu Mountain Resort and Ikom Monoliths \\
\hline 10 & Delta State & Nana Living History Museum and River Ethiope Source \\
\hline 11 & Ebonyi State & Slave Market Route and Amanchore Cave \\
\hline 12 & Edo State & The Giant Footprint of Ukhuse Oke and the Emotan Statue \\
\hline 13 & Ekiti State & Fajuyi Memorial Park and Osun River Source \\
\hline 14 & Enugu State & Ngwo Pine Forest and the Awhum Waterfall \\
\hline 15 & Gombe State & Tangle Peak and Tula Battlefield \\
\hline 16 & Imo State & Oguta Lake and Palm Beach Holiday Resort \\
\hline 17 & Jigawa State & Birnin Kudu Rock Paintings and Ringim Dying Pits \\
\hline
\end{tabular}




\begin{tabular}{|l|l|l|}
\hline S/N & LOCATIONS & TOURISM DESTINATIONS IN NIGERIA \\
\hline 18 & Kaduna State & Queen Amina's Wall and the Ancient Nok Settlement \\
\hline 19 & Kano State & Ancient Kano City Walls and Falgore Game Reserve \\
\hline 20 & Katsina State & Gobarau Minaret and Dan Marina Tomb \\
\hline 21 & Kebbi State & Karishi Traditional Settlement and the Tomb of Abdullahi Fodio \\
\hline 22 & Kogi State & World War Cenotaph and the Inikpe Statue \\
\hline 23 & Kwara State & Ahoyaya Falls and Mungo Park Cenotaph \\
\hline 24 & Lagos State & Bar Beach and the New Arika Shrine \\
\hline 25 & Nasarawa State & Farin Ruwa Waterfall and Peperuwa Lake \\
\hline 26 & Niger State & Kainji National Park and Lete Island \\
\hline 27 & Ogun State & Olumo Rock and Omo Forest Reserve \\
\hline 28 & Ondo State & Cave Ashes and Ebomi Lake Tourist Centre \\
\hline 29 & Osun State & Osun-Osogbo Grove and Erin-Ijesha Waterfalls \\
\hline 30 & Oyo State & Cocoa House and Old Oyo National Park \\
\hline 31 & Plateau State & Wase Rock and Kurra Falls \\
\hline 32 & Rivers State & Port Harcourt Tourist Beach and the Finima Nature Park \\
\hline 33 & Sokoto State & Surame and Tomb of Usman Dan Fodio \\
\hline 34 & Taraba State & Gashaka-Gumti Game Reserve and Donga River Basin Forest \\
\hline 35 & Yobe State & Dufuna Canoe and Dagona Birds Sanctuary \\
\hline 36 & Zamfara State & Kanoma Hills and Kiyawa City Walls \\
\hline
\end{tabular}

With the possession of the above named tourism potentials, the government at the state and federal levels made efforts to develop these tourism potentials. This was achieved by the establishment of diverse organizations to manage and promote the tourism sector at all governmental levels. For instance, the Lagos State government developed the tourism sector since 1985 when it was under the Ministry of home affairs. Although, the sector has been moved to different ministries, it is presently under the ministry of tourism, arts and culture. Lagos state boosts of many tourism attractions such as, the National Museum, Badagry Black Heritage Museum, Lekki Conservation Centre, New Afrika Shrine, Ikoyi Golf Club, National Arts Theatre, Freedom Park, Nike Art Gallery and Culture Centre.

Apart from Lagos State, some other states in Nigeria have been able to leverage from the economic benefits derived from tourism attractions. For the purpose of this study, the Obudu Mountain Resort which is the main thrust of the study will be critically examined. The potentials, benefits and challenges of the resort will be addressed.

\subsection{Background to the Obudu Mountain Resort}

In order to have an in-depth knowledge of the study, the origin of the Obudu Mountain Resort will be discussed. The history of the Obudu Mountain Resort is traced to the discovery by Mr. McCaughley in 1949. Although, before the discovery by McCaughley, the Mountain Resort was the hunting ground of the indigenous people that makes up the seven villages that surrounds the Resort. These villages are; Kigol, Kejukwu, Ukwamu, Okpanjanga, Keyi, Abajile and Anape. The inhabitants of these villages had lived at the Mountain for approximately fourhundred (400) years. Mr. McCaughley; a Scottish camped on the mountain for a while before returning to establish the ranch with Mr. Hugh Jones (a rancher) and retired Major Cranfield in 1951. Major Cranfield ensured the ranch's development to a well-functioning ranch-resort presently known as the Obudu Mountain Resort. He cross bred the Local Fulani Cattle, with the imported South Devon Cattle and produced a herd of several thousand cows. The cross breeding helped the beef supply company in the south-eastern part of Nigeria during the colonial period (Everipedia, 2020).

During the population census of 2006, it was discovered that the Obudu Local Government Area was overpopulated. This led to the division of the Local government area into the Obudu and Obanliku Local government areas respectively. The Mountain Resort is presently situated in Obanliku Local Government area, in the northern part of Cross River State. Although, the Mountain resort is still known as the Obudu Mountain Resort, the reason for this is not far-fetched as the name had gotten popularity nationally and globally.

The Obudu Mountain Resort is located on a flat plateau on the Oshie Ridge, one of the ridges that make up the Sankwala Mountain. The Obudu Mountain resort has a climate of about $26^{\circ} \mathrm{C}\left(78^{\circ} \mathrm{F}\right)$ to $32^{\circ} \mathrm{C}\left(89^{0} \mathrm{~F}\right)$ between November to January which may drop to $40^{\circ} \mathrm{C}\left(36^{\circ} \mathrm{F}\right)$ and $10^{\circ} \mathrm{C}\left(50^{\circ} \mathrm{F}\right)$. The lowest temperature is experienced from June to September. The best time to visit the resort is between October to December and March to May (Obudu Mountain Resort Pamphlet, 2020).

Tourism Attractions: The Obudu Mountain Resort is home to various facilities which tourists can explore for pleasure when they visit the resort. This tourism attraction includes the following;

Horse Back Riding: The tourist can enjoy riding on the back of the horse at the resort. 
Hiking: Tourist can hike in the wilderness with a tour guide.

Swimming Pool: Tourists enjoy time in the water and also relax in the outdoor pool. It is also a bonus to tourists that embraces the challenge of a three-hour hike.

Waterfall: The waterfall can get warm during the day with five hours in dry seasons (October-April) and about two hours during the rainy season (July-August).

Sport Facilities: The sport facilities in the resort include; Golf, Badminton, Lawn tennis, and Squash.

Holy Mountain: The Holy Mountain is the highest peak on the Obudu Mountain Resort. It was reportedly discovered by missionaries that visited the Obudu Mountain Resort many years ago. (Destination Cross River State Sites in People's Paradise, 2020).

Canopy Walk way: With the assistance of a tour guide; tourists can access the Canopy walkway at the Becheve Nature Reserve. The Canopy Walkway is a hundred meters $(100 \mathrm{~m})$ swaying bridge which is suspended in the air. It stands seventy meters $(70 \mathrm{~m})$ above the bottom of the forest. Taking a walk on the canopy walkway affords tourists the opportunity of enjoying the view of the beautiful forests around the Obudu Mountain Resort

The Cable Car: Tourists either drive from the bottom of the hill or take the cable car to get to the top of the resort. The hilltop is about eleven Kilometres $(11 \mathrm{~km})$ of winding road from the base. Driving up to the Mountain Resort through the devil elbow road takes about twenty minutes (25 minutes) while using the cable car takes about six minutes (6 minutes). The Cable Car has been described as the longest cable car in Africa. It affords the tourists to view the appealing vistas of the green rolling hill. The Cable car was constructed in 2005 by Ponet Nigeria Limited and Doppelmayr in Austria. It was commissioned by Former President Olusegun Obasanjo on Friday 17th June, 2005. The cable car's height bottom station: $730 \mathrm{~m}$, height top station: $1.600 \mathrm{~m}$, vertical rise: $870 \mathrm{~m}$, inclined length: $4.030 \mathrm{~m}$, drive speed: $5.00 \mathrm{~m} / \mathrm{s}$, number of towers: $12 \mathrm{pcs}$, and the rope diameter: $50.00 \mathrm{~mm}$ (The Obudu Mountain Resort Pamphlet).

Apart from the tourism attractions, the Obudu Mountain Resort offers services and has facilities that ensure the comfort of tourists. These facilities include; Conference Facilities: (The Syndicates Hall with two breakaway units having 30 people sitting capacity, Main Convention with 250 sitting capacity, and the executive Boardroom with 30 sitting capacity). The conference venues have Flip Chart, LCD Projector, PA system and Electronic White Board exclusive of the Syndicate Hall (Ogaboh Agba et al, 2010).

Services: The resort also has the following services; Bank: Guaranty Trust Bank PLC cash point with an ATM inter-switch facility just a minute walk from the reception of the resort, other banks are about an hour drive away. Clinic: a twenty-four hour medical treatment clinic is open for minor medical treatment. Gasoline Station: it is a 30-minute drive from the reception of the resort. Car Wash: it operates separately, and is about two minutes' drive from the reception. Safe Deposit Boxes: It is available at the reception because the resort does not take responsibility of loss of visitors' valuables. Business Centre: Available at the conference centres. Laundry: The resort operates an in-house laundry service. Bus Shuttle: For guest at the resort hotel, the buses pick the tourists at the reception, African hut/mountain villa and the conference centre every one hour from 6 am to $11 \mathrm{pm}$. Car Hire: The reception helps with car hire services when tourists decide to take trips outside the resort. Worship Centres: The reception gives information on time and venue for worship for interested visitors. Internet: There is twentyfour (24) hours internet for in-house visitors as access codes are gotten at the reception. (Obudu Mountain Resort Pamphlet).

\subsection{The Impact of Tourism Development in Nigeria}

Nigeria generates her internal revenue from various sources such as the petroleum sector, agriculture, manufacturing industries and through educational development. However, the most important revenue earning potential still lies on the tourism industry. This is because the tourism sector has gradually become an alternative instrument for revenue generation because of its comparative advantage. Therefore, the contribution of tourism through the Obudu Mountain Resort to the economic well-being of Cross River State and Nigeria cannot be overemphasized.

\subsubsection{Socio-cultural Impact:}

he tourism industry is a vehicle for fostering cultural exchange, which enhances mutual understanding and goodwill among the diverse peoples of the world. The resort has changed the traditional realms of crafts and arts in a socio-cultural way. For example, there are a variety of artworks and pictures in the resort that add to the experience of tourists visiting the resort.

Domestic tourism was also sponsored by the Obudu Mountain Resort, which fostered national integration among the various ethnic groups that make up Nigeria. The resort has become a segment to be evaluated by which the cultural values of the national region or community are identified and whose functions are carried out in accordance with existing principles and rules regulating the region.

Also, tourism encourages public knowledge and information, as well as tourism visits. It helps one to meet people of different backgrounds, to build understanding, peaceful coexistence, to share ideas, pleasures and to promote unity. In the context of cultural renaissance, the social effect of tourism promotes natural arts and crafts 
as mentioned above. Tourism facilitates the establishment of cordial relations between communities and nations. For example, the Obudu Mountain Resort has contributed to intergroup relations between Cross River State and its Cameroon neighbours. At the resort, some Cameroonians engage in trade relations with the tourist and indigenous people; they sell warm clothes and other wares (Amalu et al, 2012). The resort has supported the host community; as it offers financial support and resources to conserve cultural traditions, local heritage sites and customs. This has increased the quality of life of the host community.

In addition, tourism has opened the host culture to the wider world and to new experiences. It contributes to creating a positive international profile, ensuring cultural exchange and national unity, fostered by the annual Carnival and Mountain Race as the case of the Obudu Mountain Resort, Cross River State (Ashley, C., 2000).

2.4.2 Impact on the Economy:

The Obudu Mountain Resort has made an enormous contribution to the economy of Cross River State, growing the state's economic base and foreign exchange reserves through local and global tourism production. Below are some of the economic impacts of tourism:

- Infrastructural development: Tourism Infrastructure is considered to be the physical infrastructure designed and built to draw visitors. They are the tools and services required for the efficient functioning of the tourism destination. The tourism infrastructure of the Obudu Mountain Resort is divided into three categories: physical (hotels, restaurants, transport, water and electricity); cultural (cultural heritage, local art, language and food); and business (banking facilities, travel agencies and tour guides). The Obudu Mountain Resort has been an avenue for regional and state development. It has improved advantageous infrastructures to ensure the comfort of tourists (Titus, E., 2012).

- Foreign Exchange: Tourism has become a tool for progress through foreign exchange earnings and the growth of indirect and direct operations. Tourism subsidizes 5\% of the world's GDP; it is reportedly the fourth largest export after chemical, automotive and fuel goods, accounting for about $6 \%$ of the world's trade facilities. The influx of international tourists has ensured foreign exchange between Nigeria and other countries, especially in the Obudu Mountain Resort where the climate is a replica of the climate abroad. Tourists from African countries, Europe, Latin America, Asia and America patronize the tourism destination.

- Employment Opportunities: Tourism has become a major segment for job growth and incentives. It offers services to the inexperienced, pre-nominal and seasoned workforce. The Obudu Mountain Resort has produced jobs through the establishment of hotels both in the city and in the resort. Such positions are also found in public services such as hotels, airlines, travel agencies and businesses, the police, health services, fire departments and other tourism-related agencies, as well as in the development of public sector funds (Wall and Mathieson, 2007). The development of tourism in Cross River State would not have been possible without vibrant labour; workers are hired on the basis of their educational qualifications. Nonetheless, those without educational qualifications are not left out of the scheme as they provide their basic services, such as home keepers, security personals, receptionists, gardeners, dry cleaners, waiters and chefs. Tourism is an impetus to improve job prospects and thus the government has a significant role to play in creating an enabling environment for local and international tourism developers.

- $\quad$ Trade: The resort has fostered trade ties with its neighbours in Cameron, for example, at the resort some Cameroonians participate in trade relations with tourists and the indigenous people. It also promoted the selling of local products such as food, yogurt, honey, and handicrafts..

- Income: Another economic effect of tourism is the income and prosperity that it creates for the people and the country. This is further heightened by the concept of Tourism Income Multiplier (TIM). It means that a tourist's demand for an area implies spending some money with the people in those areas who, in turn, spend it elsewhere. Tourism has also boosted the economic development of the Obanliku region and generated revenue for local and state governments, even though the revenue produced has been fluctuating (Abdulrahman et al, 2014). That notwithstanding; the resort has actually contributed to the state's economy as shown in Table 2 . 
Table 2: Statistics of Funds (Obudu Mountain Resort Report)

\begin{tabular}{|l|l|l|l|l|l|c|}
\hline S/N & Months & 2015 & 2016 & 2017 & \multicolumn{1}{c|}{2018} & Total \\
\hline 1 & January & $23,181,929$ & $10,960,031$ & $13,997,323$ & $5,184,716$ & $53,323,999$ \\
\hline 2 & February & $4,081,015$ & $6,698,631$ & $4,988,616$ & 380,961 & $16,419,223$ \\
\hline 3 & March & Nil & $8,700,895$ & $6,727,746$ & $7,673,388$ & $23,102,029$ \\
\hline 4 & April & $10,725,630$ & $5,113,260$ & $2,580,646$ & $3,564,214$ & $21,983,750$ \\
\hline 5 & May & $6,400,383$ & $7,391,304$ & $10,095,719$ & 657,333 & $24,544.739$ \\
\hline 6 & June & $20,914,133$ & $6,092,706$ & $1,394,044$ & $3,752,252$ & $32,153,135$ \\
\hline 7 & July & $14,239,667$ & $11,875,328$ & $2,547,647$ & N/A & $28,662,642$ \\
\hline 8 & August & $25,474,722$ & $9,236,755$ & $1,308,895$ & N/A & $36,020,372$ \\
\hline 9 & September & $9,256,601$ & $4,681,809$ & $7,381,695$ & N/A & $21,320,372$ \\
\hline 10 & October & $5,314,819$ & $3,349,180$ & $10,404,070$ & N/A & $19,068,069$ \\
\hline 11 & November & $12,623,202$ & $17,554,966$ & $3,689,037$ & N/A & $33,867,205$ \\
\hline 12 & December & $39,069,464$ & $33,043,938$ & $20,339,785$ & N/A & $92,453,187$ \\
\hline 13 & Total & $171,281,565$ & $124,968,803$ & $85,455,223$ & $21,212,864$ & $402,918,455$ \\
\hline
\end{tabular}

2.4.3 Environmental Impact

The value of tourism development in the conservation of both natural and man-made ecosystems cannot be overestimated. Thanks to its beneficial use in these regions, it has helped to preserve and protect many historical, archaeological and cultural sites from destruction. Natural resources in Nigeria, such as national games and park facilities, are examples of such successful exploitation. The Becheve Nature Reserve in the Obudu Mountain Resort has been restored and protected by tourism, as there is knowledge of the importance of the protection of the natural environment. The Becheve Nature Reserve was used for the Gulder Ultimate Quest several years ago; the reality TV show and the nature reserve is still in good shape. Before 2004, it was very difficult for the Obanliku people to move around the communities a few hours after rainfall, but now there are good access roads all of which have been tarred with good drainage systems, reducing water pollution since 2013.

Tourism development also has negative impacts, which can gradually destroy the natural resources on which it relies. Natural breeding cycles were interrupted, for example; most of the animals in the region, such as grass cutters, bush pigs, antelopes, rats and rabbits, decreased during the rock blast at the Obudu Mountain Resort. Hunters complained that animal killing is now prohibited even though much of the landmass is not used for tourism development (Aniah et al, 2007).

Similarly, some water bodies have been sand-filled and swampy areas drained, thereby affecting some fishing zones. The estimated amount of crabs, periwinkles and prawns are no longer obtained. Also, the stone blasting seriously affected farmers, hunters and fishermen whose livelihood depended on these resources.

Furthermore, during the resort's construction a lot of medicinal herbs and roots were destroyed. These medicinal plants were used for malaria, dysentery, eye problems, and the cure for all kinds of poison, anti-snake and scorpion attack. Most people who have strongly believed in their traditional health maintenance medicine are now experiencing difficulties.

Air pollution was also found as a result of the use of vehicles, the burn fire nights normally held at the resort on weekends, and cigarette smoking as a result of the cold weather. Although, the design of the resort has helped to improve the ecological environment, preserve the historic building; strengthen the natural exotic nature of the landscape. This also affected historical monuments such as the graves of their ancestors and other shrines. (Ukabuilu et al, 2014).

- $\quad$ Preservation of Historical Sites: Tourism has made a major contribution to the preservation and renovation of many historic places and buildings. These historic sites include; Lokoja's first primary school in Northern Nigeria, King Jaja of Opobo, Monument, and Palace etc. Preservation is seen in the sense of culture, neighbourhood or individual buildings and landmarks that are historically important to the society. Tourism also involved the development of national parks, such as wildlife reserves in various regions of Nigeria; the Kainji National Park, the Borgu Game Reserve etc.

- $\quad$ Environmental Conservation: Tourism has aided natural habitat protection such as trees, and forests which are essential for ecotourism. Tourism has also ensured the conservation of species on the brink of extinction, by setting up wildlife reserves with precise laws to protect these animals; by attracting nature-loving visitors and also ensured the conservation of endangered species (Lussetyowati, T., 2015).

\section{Discussions of Research Findings}

It is claimed that the Obudu Mountain Resort had been constantly patronized as a resort of significance in Nigeria because of its seclusion which rather makes it a unique resort. However, the findings from the research in figure two showed that the patronage of the Obudu Mountain Resort reduced drastically because of some challenges. The challenges include poor tourism infrastructural development, insecurity, and lack of sufficient funds for the 
rejuvenation and maintenance of the Obudu Mountain Resort. These challenges have on the long run posed a serious threat to tourists' patronage of the Obudu Mountain Resort at the international and domestic levels as seen in Figure 2.

Figure 2: Patronage of the Obudu Mountain Resort (Author's Field Survey, 2020)

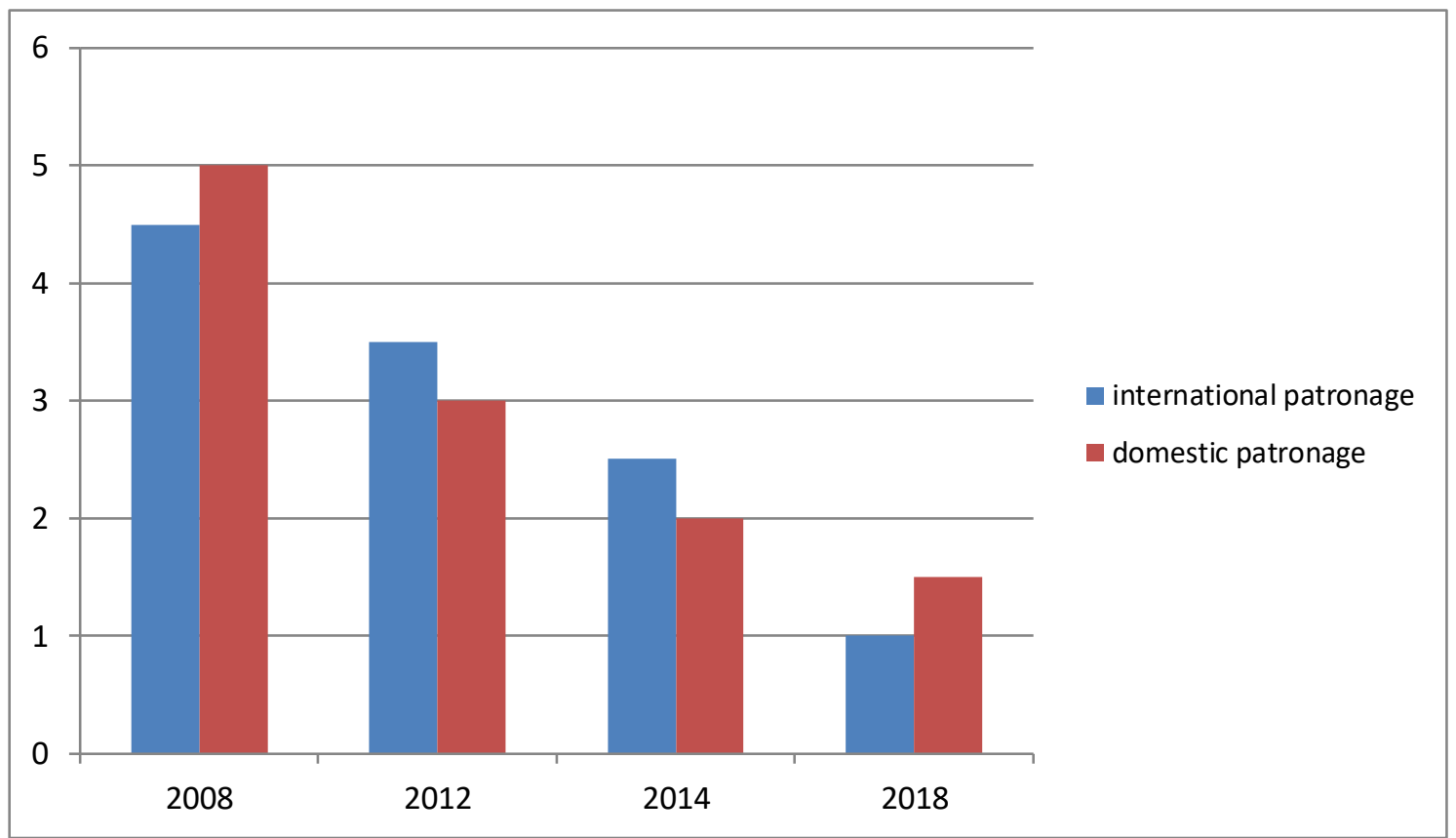

The argument presented in the study is that if economic development in Nigeria is concerned with the nature and causes, that is the determination of the standard of living then tourism should form one of these pillars for development. Consequently, the position of this work is indeed concerned with the question of WHY and HOW the tourism industry particularly the Obudu Mountain Resort has found itself in such a position of not generating enough to support its fit.

In order to justify some of their problematic, this study critically questioned the role played by the government (both state and federal) in promoting growth and development and therefore improving the quality of life of the citizens. This inference is drawn from the fact that if the quality of life of the citizens is not effective and balanced then the issue of relaxation, tourism attractions and recreation will only remain an illusion for the greater part of the population.

With Nigeria's population standing at over 200 million persons, it therefore means that those who may be genuinely eligible to have time for leisure and recreation may not just be more than a mere gestation of five per cent $(5 \%)$ of the population. Obviously, this $5 \%$ would certainly be found among the wealthy or the privileged class. In effect that pre-suggest that despite the input of the ruling class or so to say top government officials enjoying tourism facilities, it will only be limited to those who are qualified for the use of such facilities in their leisure periods. The outcome of the study indicates that the viability of the tourism industry that is Obudu Mountain Resort is intricately linked to the economic situation of not just the state but of the entire nation. It therefore becomes probable that if the quality of life of the citizenry is appropriately enhanced in terms of good employment opportunities, good business orientation and governmental support, private initiative and involvement in projects and industries, then the citizenry would definitely have time and the wherewithal to patronize such places in their leisure periods. Otherwise, not much would be expected from a national population/citizenry struggling to make ends meet.

Alongside a good tourism site or investment should be encouraged through industrial development including business facilities which will attract employment in the Obanliku Local government area. The development of the Obudu Mountain Resort should not be limited to those tourism facilities. Other economic indices such as factories, business concerns, industries, public/ private participation which can swell the population of the area and ultimately swell patronage of the Obudu Mountain Resort should similarly be put in place to enhance growth and development.

In effect, the argument of the research is that every project and economic initiative which is directed at the economic development of a society should take into account the accompanying factors that could enable or enhance the realization of such lofty ideals. What are the goods and services needed to ensure that the tourism industry would be financially result-oriented?

From the economic point of view, if the amenities and the society do not have enough input then it would be 
difficult to generate an output which will be commensurate to the expectations therein as the problem of the Obudu Mountain Resort. Wherein, the government may have invested to their own projections, can it be realistically sustained from the economic point of view that what has been put in place in Obudu Mountain Resort today is enough to attract leisure seekers not just from the other West African and African countries but also internationally? The answer is indeed, not justifiable in the positive affirmation.

Also, not much has been done in publicity and sensitization from various sources of media locally, nationally and internationally on the Obudu Mountain Resort. This mechanism should enhance the patronage of the Obudu Mountain Resort, if effectively utilized.

Nigeria is often considered to be one of the capitalist economy practitioners which allow the operation of the price mechanism to dictate major economic decisions. Although, it has been argued that the country operates a mix economic system, in this system the government owns a substantial proportion of the major investment. It however allows a considerable amount of privet ownership of means of production. Going by these economic suppositions, it may be argued that the government of Cross River State did actually involve private ownership to a certain level in the development of the resort. What is therefore questionable are the extent to which both parties have reconciled their financial commitment and the extent to which their expected results can be marginalized. If these issues and major concerns have not been genuinely brought to the table for resolution then it might be unthinkable that achieving such lofty heights expected by the state government may not immediately be realizable.

This is not however, to suppose that it is impossible to build an Obudu Mountain Resort that will be a successful project and pride of the nation if proper attentions, government incentives are properly put in place to achieve these dreams.

\section{Conclusion}

In light of the above submission, the study revealed that the tourism development assessment in Nigeria shows that while developing nations like Nigeria have a massive capacity for tourism, the sector needs to be promoted and built to accumulate welfare. Historically, it is evident from the tourism list that the Obudu Mountain Resort is one of the oldest with strong links to colonial government of Nigeria. Given its age and importance more is expected of this tourism destination. Nonetheless, strict efforts should be made to reduce the challenges associated with tourism in the country.

Accordingly, the study concludes that the tourism sector has the capacity to be a major player in the economic activities of the country. This is because of the diverse tourism attractions and tourism potentials of the country which cannot be underestimated. The capability and capacity of the tourism sector to be an alternative means for economic growth is not far-fetched. As the tourism attractions of the country are majorly natural and cultural/historic hence the only responsibility of the government is to invest in tourism infrastructure which at the long run will be able to ensure sustainable tourism development.

The study recommends that a comprehensive effort be made to rejuvenate the Obudu Mountain Resort which is germane for economic development and diversification. As noted earlier, this can be achieved in the field of infrastructure, economic growth in the region by attracting foreign investment and by introducing appropriate security measures.

\section{References}

Abdulrahman, N., Muhammad S., Muhammad Y. H. 2014.The Possible Impact of Tourism Industry on Nigeria's economy. Review of Public Administration and Management, 3 (5), pp.68-74.

Adebayo, A. D. 2018. Governance and Community Participation in the Nigerian Tourism Sector: A Stakeholders Analysis.

Amalu, T., Ajake, A., Oba, D. and Ewa, E. 2012. An Assessment of Tourism Benefits to the Becheeve People of the Obudu Mountain Resort, Cross River State, Nigeria. Greener Journal of Social Sciences, 2(1), pp.28-40.

Aniah, E., Eni, D., Abua, M. and Amama, M. 2007. Geospatial modelling of the Obudu cattle ranch Cross River state, Nigeria. Lwati: A Journal of Contemporary Research, 4(1).

Ashley, C., 2000. "The Impacts of Tourism on Rural Livelihood: Namibia's Experience”, Oversees Development Institute (ODI), London Working Paper, 128, pp.5-31.

Bankole, A., 2002. The Nigerian Tourism Sector: Contribution, Constraints, and Opportunities. The Journal of Hospitality Financial Management, 10(1), pp.71-89.

BuzzNigeria - Famous People, Celebrity Bios, Updates and Trendy News. 2019. Obudu Cattle Ranch And Mountain Resort - Here's All You Need To Know. [online] Available at: <https://buzznigeria.com/obudumountain-resort/> [Accessed 30 December 2019].

Cometonigeria.com.2019.Tourist Attractions in Nigeria [online]. Available at: https://www.cometonigeria.com. [Accessed 27 Sep. 2019].

Destinali. 2020. Obudu Cattle Ranch (Obudu Mountain Resort) | Destinali. [online] Available at: https://destinali.com/locations/obudu-cattle-ranch-obudu-mountain-resort/ [Accessed 6 Jan. 2020]. 
Encyclopedia Britannica. 2020. Tourism | Definition, History, Types, Importance, \& Facts. [online] Available at: $<$ https://www.britannica.com/topic/tourism> [Accessed 5 February 2020].

Everipedia.org.2020.Everipedia.[online]Availableat:https://everipedia.org/wiki/lang_en/Obudu_Mountain_Resor $\mathrm{t}$ [Accessed 4 Jan. 2020].

Lussetyowati, T., 2015. "Preservation and Conservation through Cultural Heritage Tourism. Case Study: Musi Riverside Palembang", Social and Behavioural Sciences, 814, pp.401-406.

Munzali, A. D., 2020. Tourism Development in Nigeria: Challenges and Prospects for Resource Diversification. National Institute for Hospitality and Tourism (Nihotour), Abuja, Nigeria.

Nigeriagalleria.com. 2019. Brief History Of Cross-River State:: Nigeria Information \& Guide. [online] Available at: $\quad<$ https://www.nigeriagalleria.com/Nigeria/States_Nigeria/Cross-River/Brief-History-of-Cross-RiverState.html> [Accessed 28 December 2019].

Nordeatrade.com. 2020. The Economic Context Of Nigeria - Economic And Political Overview - Nordea Trade Portal. [online] Available at: <https://www.nordeatrade.com/no/explore-new-market/nigeria/economicalcontext $>$ [Accessed26January 2020].

Ogaboh A. A., Ikoh, M., Bassey, A. and Ushie, E. [2010]. Tourism industry impact on Efik's culture, Nigeria. International Journal of Culture, Tourism and Hospitality Research, 4(4), pp. 355-365.

Punch Newspapers. 2019. Tourism Capable Of Outshining Oil As Nigeria'S Revenue Earner -Omolewa, ExUNESCO Ambassador. [online] Available at: <https://punchng.com/tourism-capable-of-outshining-oil-asnigerias-revenue-earner-omolewa-ex-unesco-ambassador/> [Accessed 12 December 2019].

Terwase, I. T. et al, 2015. Obudu Cattle Ranch: A Tourist Destination in Nigeria. Journal of Humanities and Social Sciences, 5 .

Theculturetrip.com.2019.The Top 10 Heritage Sites in Nigeria [online]. Available at: https://theculturetrip.com [Accessed 25 Sep. 2019].

The Guardian Nigeria News - Nigeria and World News. 2020. Destination Cross River... tourist sites in people's paradise | The Guardian Nigeria News - Nigeria and World News. [online]. Available at: https://guardian.ng/saturday-magazine/destination-cross-river-tourist-sites-in-peoples-paradise/ [Accessed 9 Jan. 2020].

The Obudu Mountain Resort pamphlet retrieved from the Obudu Mountain Resort, Cross River State.

Titus E., A. 2012. Socio-Economic Implication of Tourists' Appraisal of the Obudu Mountain Resort, Cross River State, Nigeria. IOSR Journal of Environmental Science, Toxicology and Food Technology, 1(3), pp.37-44.

Tripadvisor. 2019. Cross River State Tourism (2019): Best Of Cross River State - Tripadvisor. [online] Available at: <https://www.tripadvisor.in/Tourism-g3652165-Cross_River_State-Vacations.html> [Accessed 12 December 2019]..

Ukabuilu, E., Igbojekwe, P. A., Uzoho, P. (2014), “An Assessment of Environmental Impact of Developed Tourism Projects in Selected Sites in Cross River State, Nigeria", International Journal of Education and Research, 2(10), pp.397- 402.

Wall, G. and Mathieson, A. 2007. Tourism. Harlow, United Kingdom: Pearson Education Canada

Wikipedia.org . 2020. Economic Development. [online]. Available at: https://en.m.wikipedia.org [Accessed 5 Feb. 2020]. 